\title{
Endophytic fungi of Brunfelsia uniflora: Isolation, cryopreservation, and determination of enzymatic and antioxidant activity
}

Sara Jane Marsola ${ }^{1}$ Lais Freitas Jorge ${ }^{1}$. Adriano Borges Meniqueti ${ }^{1}$ Miria Benetati Delgado Bertéli ${ }^{1}$ Thaís Emanuelle Feijó de Lima ${ }^{2}$ José Luiz Bezerra $^{2}$ Ana Daniela Lopes ${ }^{1}$ Zilda Cristiani Gazim ${ }^{1}$ Juliana Silveira do Valle ${ }^{1}$ Nelson Barros Colauto ${ }^{3}$ Giani Andrea Linde ${ }^{4}$

Received:

(C) The Author(s), under exclusive licence to Springer Nature B.V. 2021

Ana Daniela Lopes

anadanielalopes@prof.unipar.br

ORCID: https://orcid.org/0000-0003-2027-5741

${ }^{1}$ Universidade Paranaense, Graduate Program of Biotechnology Applied to Agriculture, Umuarama 87502-210, Brazil

${ }^{2}$ Universidade Federal do Recôncavo da Bahia, Cruz das Almas 44380-00, Brazil

${ }^{3}$ Federal University of Bahia, Ondina Campus, Graduate Program in Food Science - Faculty of Pharmacy, Salvador 40110-115, Brazil

${ }^{4}$ Federal University of Bahia, Canela Campus, Graduate Program in Food, Nutrition and Health - School of Nutrition, Salvador 40110-907, Brazil

\section{Abstract}

Brunfelsia uniflora (Pohl.) D. Don (Solanaceae), commonly known as manacá-de-cheiro, is widely distributed in Brazil and used by local indigenous peoples as an antirheumatic, antisyphilitic, depurative, emetic, vermifuge, and purgative agent. Several studies have examined the biological activities and phytochemical profile of Brunfelsia; however, few have focused on the diversity of endophytic microorganisms that colonize members of the genus. This study aimed to isolate and cryopreserve endophytic fungi from $B$. uniflora and determine their cellulase, laccase, and antioxidant activities. Endophytic fungi were isolated from B. uniflora stems, cultured on wheat grains, immersed in a $150 \mathrm{~g} \cdot \mathrm{L}^{-}$ ${ }^{1}$ aqueous sucrose solution, and cryopreserved at $-80^{\circ} \mathrm{C}$ for 1 and 6 months. Cellulase activity was determined by a qualitative test using carboxymethylcellulose medium and laccase activity by a quantitative test based on the oxidation of 2,2'-azino-bis(3-ethylbenzothiazoline-6-sulfonate). Prior to antioxidant activity assays, fungi were grown in malt extract broth for production of mycelial biomass. A methanolic extract was prepared for evaluation of $D P P H \bullet$ scavenging activity, FRAP activity, and total phenolic content. A total of 46 endophytic fungal isolates were obtained from $B$. uniflora stems and classified into 24 groups according to morphological similarities. B. uniflora was shown to harbor a great diversity of endophytic fungi. Mycelial viability was observed after 1 and 6 months of cryopreservation at $-80{ }^{\circ} \mathrm{C}$. Fungi exhibited cellulase and laccase activities. Isolate CE23 had the highest laccase activity after 7 days of cultivation. Twelve isolates were found to have low total phenolic contents and $D P P H \bullet$ and FRAP activities.

Keywords: Preservation of microorganisms; medicinal plant; enzyme; diversity; symbiosis. 


\section{Introduction}

Endophytic fungi are a diverse group of microorganisms that inhabit plant tissues during part of their life cycle (Guo et al., 2008; Hardoim et al., 2008; Saikkonen, 2007; Sun et al., 2008; Xia et al., 2011). Depending on environmental conditions and plant physiological state, these fungi may become pathogenic, although infections are usually asymptomatic. Endophytic fungi may also interact mutualistically with plants (Compant et al., 2010; Davitt et al., 2011; Gundel et al., 2011; Hardoim et al., 2008). In some cases, nematodes can be controlled by endophytes, such as Fusarium oxysporum, which produces metabolites that are antagonistic to the nematode Meloidogyne incognita. Endophytic fungi can produce compounds with insecticidal and nematicidal activities, protecting host plants from pests and pathogens (Mejía et al., 2008). Furthermore, endophytic fungal metabolites may have antimicrobial, cytotoxic, and anticancer activities (Zhao, 2010). Some endophytic fungi seem to have developed the ability to produce the same or similar compounds as those produced by host plants (Kour et al., 2008). This finding has stimulated research on the relationship between endophytes and their hosts, enabling the development of alternative processes for obtaining bioactive substances (Gunatilaka, 2006; Zhao, 2010).

For instance, paclitaxel, an important anticancer drug isolated from the plant Taxus brevifolia, is also produced by the endophytic fungus Taxomyces andreanae. Vincristine, another important anticancer agent, is produced by the plant Catharanthus roseus and was recently isolated from Fusarium oxysporum, an endophyte of $C$. roseus (Jalgaonwala et al., 2011). The pharmacological action of plants seems to be intimately related to plant-endophytic interactions. Therefore, evaluation of the endophytic microbiota of medicinal plants is fundamental for the advancement of herbal medicine use in animals, especially humans, as well as for the production of food and cosmetics.

Brunfelsia uniflora (Pohl.) D. Don (Solanaceae), commonly known as manacá-de-cheiro, occurs in several regions of Brazil, Bolivia, Peru, Ecuador, Colombia, and Venezuela. This shrubby plant has simple leaves and purple or white inflorescences or single flowers. Different species of Brunfelsia are used by indigenous peoples as, antirheumatic, antisyphilitic, depurative, vermifuge, and purgative agents (Schultes, 2018). Phytochemical studies of the aerial parts of Brunfelsia species revealed the presence of 
active compounds, such as benzenoids, terpenes, lactones, alkaloids, and lipids (Brunner et al., 2000; Castioni \& Kapetanidis, 1996; Mors \& Ribeiro, 1957; Ruppelt et al., 1991). Although numerous studies have been carried out on Brunfelsia phytochemical compounds, none have investigated the diversity of endophytic microorganisms in these plants.

An important factor for the study of endophytic fungi, their diversity and quantity, and their ability to produce bioactive molecules is their preservation. There are numerous techniques for preserving fungi. The most common is the periodic subculturing of fungal fragments on growth media. However, this method is laborious, occupies space in culture collections, and is subject to accidental contamination by other microorganisms and loss of biological, genetic, or physiological characteristics. Other short-term preservation methods involve the use of mineral oil and distilled water, but variations in morphology, physiology, and mycelial viability might occur proportionally to the duration of preservation (Humber, 1997). Fungi can also be preserved in the form of spores by freeze-drying; however, this technique has not proven suitable for maintaining mycelial integrity (Homolka et al., 2003). Studies conducted by our research group have shown that freeze-drying of mycelia does not result in efficient preservation of basidiomycetes. Cryopreservation is still considered the safest, most reliable and effective method of mycelium preservation, as it inactivates fungal metabolism and has a low risk of contamination and genetic degeneration (Ito \& Nakagiri, 1996).

Endophytic microorganisms are possibly an unexplored source of enzymes such as cellulases and laccases. These enzymes are used in the textile, food (A. Singh et al., 2021), cosmetics (Shin et al., 2019), paper, and pulp industries (G. Singh \& Arya, 2019; Yang et al., 2019) as well as in bioremediation (Sharma et al., 2018). The use of enzymes in biotechnological processes has been constantly growing. According to BCC Research, the global demand for enzymes will grow 5\% per year, reaching US\$7 billion by 2023.

In addition to producing enzymes, endophytic fungi synthesize antioxidant compounds that protect against free radicals, contributing to disease prevention. There are few reports on the topic (Strobel \& Daisy, 2003). Of note, pestacin and isopestacin were obtained from the fungus Pestalotiopsis microspora, an endophyte of Terminalia morobensis (Harper et al., 2003; Strobel et al., 2002). Both pestacin (Harper et al., 2003) and isopestacin (Strobel \& Daisy, 2003) exhibit antioxidant (IC50 of $1.7 \mathrm{mM}$ and $0.185 \mathrm{mM}$, 
respectively) and antibacterial activities (Strobel \& Daisy, 2003). In view of the scarcity of studies aimed at the diversity, preservation, and enzymatic and antioxidant activities of endophytic fungi from medicinal plants, this study aimed to isolate, cryopreserve, and determine the biological activity of endophytic fungi isolated from stems of B. uniflora.

\section{Materials and Methods}

\section{Isolation of endothytic fungi}

B. uniflora was cultivated in the medical garden of the Paranaense University, Brazil, and specimens were deposited in the educational herbarium of the Paranaense University (HEUP) under accession no. 2855. Branches were collected and washed twice under running water and distilled water. Endophytic fungi were isolated according to the methods of Pereira et al. (1993) and Petrini (1991), with modifications. Under a laminar flow hood, leaves were removed, and stems were immersed in $1 \%$ (v/v) sodium hypochlorite solution for $3 \mathrm{~min}$, washed in distilled water, immersed in $70 \%$ (v/v) ethanol for $1 \mathrm{~min}$, immersed in $90 \%$ (v/v) ethanol for $30 \mathrm{~s}$, and washed twice in autoclaved ultrapure water.

To assess the effectiveness of sample disinfection, we inoculated $100 \mu \mathrm{L}$ of ultrapure water from the last washing step on potato dextrose agar (PDA) $\left(39.0 \mathrm{~g} \cdot \mathrm{L}^{-1}\right.$, HiMedia) previously autoclaved at $121^{\circ} \mathrm{C}$ for 20 min. Water was spread on PDA using a Drigalski spatula, and plates were kept in the dark at $25^{\circ} \mathrm{C}$ for 2 days. Lack of microbial growth indicated that the disinfection procedure was effective.

After disinfection, stems were cut into 3-5 mm fragments. Five stem fragments were placed in Petri dishes containing PDA medium (10 replicates) to investigate the effectiveness of stem surface disinfection and five on PDA medium supplemented with ampicillin and streptomycin (20 replicates) to prevent bacterial growth and promote fungal growth. For this, culture medium was autoclaved, cooled at $50{ }^{\circ} \mathrm{C}$, and mixed with $0.2 \mathrm{~g} \cdot \mathrm{L}^{-1}$ ampicillin sodium salt and $0.2 \mathrm{~g} \cdot \mathrm{L}^{-1}$ streptomycin sulfate. Plates were incubated in the dark at $25^{\circ} \mathrm{C}$, and emerging fungi were plated on PDA containing antibiotics (PDA+) until a pure culture was obtained. After obtaining pure cultures, we maintained fungi by periodic subculturing on PDA

medium at $25{ }^{\circ} \mathrm{C}$ in the dark. Fungi were examined using a stereoscopic microscope (Motic, SMZ168 series) and grouped according to morphological characteristics, such as mycelial color, branching, and 
edge, culture medium color, and spore color. Spores and hyphae were examined by taking photomicrographs of isolates. Samples were obtained from culture media using transparent adhesive tape, transferred to a glass slide, and stained with malachite green.

\section{Identification of endophytic fungal isolates}

Fungal isolates were sent to the Laboratory of Microbiology of the Federal University of Recôncavo da Bahia for taxonomic identification. At the laboratory, mycelial fragments were cultured on PDA plates. Then, the fungi were inoculated on different media in an attempt to promote sporulation, such as Sabouraud dextrose agar $\left(10 \mathrm{~g} \cdot \mathrm{L}^{-1}\right.$ peptone, $40 \mathrm{~g} \cdot \mathrm{L}^{-1}$ dextrose, and $15 \mathrm{~g} \cdot \mathrm{L}^{-1}$ agar $), 2 \%$ malt extract agar $(20$ $\mathrm{g} \cdot \mathrm{L}^{-1}$ malt extract and $15 \mathrm{~g} \cdot \mathrm{L}^{-1}$ bacteriological agar $)$, oatmeal agar, yeast extract agar $\left(5 \mathrm{~g} \cdot \mathrm{L}^{-1}\right.$ yeast extract, $20 \mathrm{~g} \cdot \mathrm{L}^{-1}$ dextrose, and $12 \mathrm{~g} \cdot \mathrm{L}^{-1}$ agar $)$, and $\mathrm{V} 8$ agar $\left(200 \mathrm{~mL} \cdot \mathrm{L}^{-1}\right.$ packaged tomato juice, $3 \mathrm{~g} \cdot \mathrm{L}^{-1} \mathrm{CaCO}_{3}, 5$ $\mathrm{g} / \mathrm{L}$ dextrose, and $20 \mathrm{~g} \cdot \mathrm{L}^{-1}$ agar). When necessary, fungi were cultured in a small block of agar at the center of microscopic slides (Riddell, 1950). Identification at the genus and species levels was based on macrostructural characteristics, such as medium color (surface and reverse) and mycelial growth and texture, as well as on microstructural characteristics, such as mycelium type, conidiophores, presence of spores, spore size, shape, color, and resistance structures (chlamydospores). Identification keys were used as references (Barnett \& Hunter, 1986; Domsch et al., 2008; Kirk \& Cooper, 2005; Sutton, 1980).

\section{Cryopreservation}

The first step was to prepare the fungal inocula for cryopreservation. For this, wheat 'IPR-136 IAPAR' grains were washed under running water, washed three times with ultrapure water, and cooked at $90{ }^{\circ} \mathrm{C}$ for $45 \mathrm{~min}$ in $\mathrm{CaCO} 3$ solution (1.5\%). After cooking, excess water was removed, the grains were transferred to $15 \mathrm{~mL}$ Falcon tubes and autoclaved at $121{ }^{\circ} \mathrm{C}$ for $90 \mathrm{~min}$ (Mata and Estrada 2005). One tube was used for $\mathrm{pH}$ determination; wheat grains were ground with a glass rod, homogenized with ultrapure water, and analyzed using a $\mathrm{pH}$ meter. The $\mathrm{pH}$ was found to be 6.9. The remaining tubes were inoculated with a PDA disk containing mycelia and kept in the dark at $25^{\circ} \mathrm{C}$ for 15 days.

For cryopreservation, $8 \mathrm{~mm}$ diameter plastic straws were cut into $6 \mathrm{~cm}$ pieces, heat-sealed at one end, and used as cryotubes (Challen \& Elliot, 1986) after autoclaving at $121{ }^{\circ} \mathrm{C}$ for $15 \mathrm{~min}$ (Mantovani, 2008). Under a laminar flow hood, the wheat grain solution was filtered through a $0.22 \mu \mathrm{m}$ membrane filter (low 
protein binding PVDF membrane, Durapore $\left.{ }^{\circledR}\right)$ and each cryotube received 5 wheat grains or 5 PDA disks colonized by fungi and $1 \mathrm{~mL}$ of sucrose solution $\left(150 \mathrm{~g} \cdot \mathrm{L}^{-1}\right)$. Cryotubes were heat-sealed at the other end and stored in an ultrafreezer at $-80{ }^{\circ} \mathrm{C}$ (Colauto, Cordeiro, et al., 2012).

\section{Recovery of cryopreserved fungi}

At 1 and 6 months after cryopreservation, three cryotubes per treatment were removed from the ultrafreezer and evaluated for mycelial viability. Briefly, cryotubes were removed from the ultrafreezer and placed in a water bath at $30^{\circ} \mathrm{C}$ for $15 \mathrm{~min}$. Under a laminar flow hood, cryotubes were immersed in 70\% and 95\% ethanol for surface cleaning (Colauto et al., 2011; Colauto, Cordeiro, et al., 2012; Colauto, Da Eira, et al., 2012). One end of the cryotube was cut off and the cryoprotectant removed. Five wheat grains and five PDA discs containing cryopreserved fungi were plated on PDA medium previously autoclaved at $121{ }^{\circ} \mathrm{C}$ for $20 \mathrm{~min}$. Then, plates were kept in the dark at $25{ }^{\circ} \mathrm{C}$, and mycelial growth was monitored daily. Each wheat grain or PDA disk represented one replicate, totaling five replicates per treatment. To evaluate fungal recovery, we assessed whether there was mycelial growth on PDA medium.

\section{Cellulase activity}

A qualitative test was used to assess the cellulase activity of mycelial extracts (Sunitha et al. 2013). Petri dishes with carboxymethylcellulose $(\mathrm{CMC})$ medium $\left(10 \mathrm{~g} \cdot \mathrm{L}^{-1} \mathrm{CMC}, 1.4 \mathrm{~g} \cdot \mathrm{L}^{-1}\left(\mathrm{NH}_{4}\right)_{2} \mathrm{SO}_{4}, 2.0 \mathrm{~g} \cdot \mathrm{L}^{-1}\right.$ $\mathrm{KH}_{2} \mathrm{PO}_{4}, 0.3 \mathrm{~g} \cdot \mathrm{L}^{-1} \mathrm{MgSO}_{4}, 0.3 \mathrm{~g} \cdot \mathrm{L}^{-1} \mathrm{CaCl}_{2}, 0.25 \mathrm{~g} \cdot \mathrm{L}^{-1}$ yeast extract, $0.75 \mathrm{~g} / \mathrm{L}$ casein peptone, $17 \mathrm{~g} \cdot \mathrm{L}^{-1}$ agar, and $10 \mathrm{~mL} / \mathrm{L}$ mineral solution containing $0.5 \mathrm{~g} \cdot \mathrm{L}^{-1} \mathrm{CaCl}_{2}, 0.4 \mathrm{~g} \cdot \mathrm{L}^{-1} \quad \mathrm{MnSO}_{4} \cdot \mathrm{H}_{2} \mathrm{O}, 0.35 \mathrm{~g} \cdot \mathrm{L}^{-1}$ $\mathrm{ZnSO}_{4} \cdot \mathrm{H}_{2} \mathrm{O}$, and $0.125 \mathrm{~g} \cdot \mathrm{L}^{-1} \mathrm{FeSO}_{4} \cdot \mathrm{H}_{2} \mathrm{O}$ ) were inoculated with a $6 \mathrm{~mm}$ diameter disk of PDA containing fungal mycelia. Plates were incubated at $21^{\circ} \mathrm{C}$ and monitored for growth during 7 days. After this period, each plate was flooded with $10 \mathrm{~mL}$ of Congo red $\left(2 \mathrm{~g} \cdot \mathrm{L}^{-1}\right.$ Congo red in $1 \mathrm{M}$ Tris- $\mathrm{HCl}, \mathrm{pH}$ 8.0) and kept for $10 \mathrm{~min}$ at room temperature. Then, the dye solution was removed, and plates were washed twice with $1 \mathrm{M} \mathrm{NaCl}$ to reveal the cellulolytic halo. Mycelium and halo diameters were measured at three equidistant points using a caliper. The enzymatic index was calculated as the ratio of the mean halo diameter to the mean mycelium diameter (Sunitha et al., 2013). Fungi with an enzymatic index greater than 1 were considered as potential cellulase producers. 


\section{Laccase activity}

For analysis of laccase activity, fungi were inoculated in $250 \mathrm{~mL}$ Erlenmeyer flasks containing $100 \mathrm{~mL}$ of culture broth $\left(1.5 \mathrm{~g} \cdot \mathrm{L}^{-1} \mathrm{KH}_{2} \mathrm{PO}_{4}, 1.023 \mathrm{~g} \cdot \mathrm{L}^{-1} \mathrm{MgSO}_{4} \cdot 7 \mathrm{H}_{2} \mathrm{O}, 0.5 \mathrm{~g} \cdot \mathrm{L}^{-1} \mathrm{KCl}, 0.036 \mathrm{~g} \cdot \mathrm{L}^{-1} \mathrm{FeSO}_{4} \cdot 7 \mathrm{H}_{2} \mathrm{O}\right.$, $0.035 \mathrm{~g} \cdot \mathrm{L}^{-1} \mathrm{ZnSO}_{4} \cdot 7 \mathrm{H}_{2} \mathrm{O}$, and $10 \mathrm{~g} \cdot \mathrm{L}^{-1}$ glucose; (Pontecorvo et al., 1953) and autoclaved at $121^{\circ} \mathrm{C}$ for 20 min. Then, urea $\left(6 \mathrm{~g} \cdot \mathrm{L}^{-1}\right)$ was added and the flasks inoculated with four discs $(\sim 6 \mathrm{~mm}$ diameter $)$ of fungal mycelia, in triplicate. Samples were incubated at $25{ }^{\circ} \mathrm{C}$ for 10 days. Enzyme activity was analyzed every $24 \mathrm{~h}$ during this period.

Laccase activity was determined by measuring the oxidation of 2,2'-azino-bis(3ethylbenzothiazoline-6-sulfonic acid (ABTS), according to Cardoso et al. (2018). Briefly, $200 \mu \mathrm{L}$ of crude extract, $700 \mu \mathrm{L}$ of water, $450 \mu \mathrm{L}$ of sodium acetate buffer (0.1 M, pH 5.0), and $150 \mu \mathrm{L}$ of ABTS (1 mM) were added to a test tube. Tubes were kept at $30{ }^{\circ} \mathrm{C}$ for $10 \mathrm{~min}$ and the increase in absorbance was monitored at $420 \mathrm{~nm}\left(\varepsilon=36000 \mathrm{M}^{-1} \mathrm{~cm}^{-1}\right)$. Two analytical controls were used, one without crude extract and the other without ABTS. Experiments were performed in two replications. One unit (U) of enzyme activity was defined as the amount of enzyme required to oxidize $1 \mu \mathrm{mol}$ of ABTS in 1 min of reaction.

\section{Determination of antioxidant activity}

The first step was to obtain sufficient mycelial biomass for analysis. Four $6 \mathrm{~mm}$ discs containing the mycelium of isolated fungi were transferred to a $250 \mathrm{~mL}$ Erlenmeyer flask containing $100 \mathrm{~mL}$ of malt extract broth $\left(20 \mathrm{~g} \cdot \mathrm{L}^{-1}\right)$ and kept under agitation at $85 \mathrm{rpm}$ and $25^{\circ} \mathrm{C}$ for 3 to 5 days. Fungal biomass was collected by filtration and dried in a forced-air oven at $60{ }^{\circ} \mathrm{C}$ for 2 days. After drying, the biomass was ground with mortar and pestle and the resulting powder used for extract preparation. Ground dry biomass (1 g) was homogenized with $10 \mathrm{~mL}$ of methanol in $50 \mathrm{~mL}$ Falcon tubes. The mixture was kept at $60{ }^{\circ} \mathrm{C}$ for $60 \mathrm{~min}$, then cooled in an ice bath for $10 \mathrm{~min}$, and centrifuged at $4000 \times \mathrm{g}$ and $5{ }^{\circ} \mathrm{C}$ for $10 \mathrm{~min}$. The supernatant was collected and used as crude extract.

\section{Total antioxidant activity (DPPH• assay)}

Total antioxidant activity was assessed by the $D P P H \bullet$ (2,2-diphenyl-1-picrylhydrazyl) assay, according to Brand-Williams et al. (1995), with modifications. The method is based on the color change from purple to yellow as $D P P H \bullet$ is reduced by electron transfer. 
Crude extracts were first tested at a single concentration. For this, $3.9 \mathrm{~mL}$ of a methanolic solution of $D P P H \bullet(60 \mu \mathrm{M})$ was homogenized with $100 \mu \mathrm{L}$ of crude extract. After $30 \mathrm{~min}$, the absorbance was read at $515 \mathrm{~nm}$ on a UV/Vis spectrophotometer. Total antioxidant activity was calculated against a standard solution of quercetin $(60 \mu \mathrm{M})$, taken as a reference (100\% activity) (Molyneux, 2004).

Fungi with antioxidant activity in the screening test were selected for IC50 determination. First, $D P P H \bullet$ solutions at $0,10,20,30,40$, and $60 \mu \mathrm{M}$ were prepared in methanol. Then, $3.9 \mathrm{~mL}$ of each $D P P H \bullet$ solution was homogenized with $100 \mu \mathrm{L}$ of methanol. After $30 \mathrm{~min}$, absorbance readings were taken at 515 $\mathrm{nm}$ on a UV/Vis spectrophotometer, and the absorbance corresponding to $50 \%(30 \mu \mathrm{M})$ of the initial $D P P H \bullet$ concentration $(60 \mu \mathrm{M})$ was calculated. Subsequently, crude extracts were diluted with methanol to concentrations of $33,25,16,8,4$, and $2 \mathrm{mg} \cdot \mathrm{mL}^{-1}$. For determination of antioxidant activity, $3.9 \mathrm{~mL}$ of $D P P H \bullet$ methanolic solution $(60 \mu \mathrm{M})$ was homogenized with $100 \mu \mathrm{L}$ of crude extracts at different concentrations, samples were left to rest for $30 \mathrm{~min}$, and absorbance was measured at $515 \mathrm{~nm}$. Solutions of quercetin at $0,10,20,30,40$, and $60 \mu \mathrm{M}$ were used as positive controls. The concentration of extract required to inhibit $50 \%$ of free radicals in the sample (IC50) was determined by plotting absorbance versus sample concentration. Experiments were performed in triplicate.

\section{Ferric reducing antioxidant power (FRAP)}

The FRAP assay was performed as described by Benzie and Strain (1996), with modifications. The method is based on the reduction of the $\mathrm{Fe}^{3+} / 2,4,6$-tris(2-pyridyl)-s-triazine (TPTZ) complex to a blue $\mathrm{Fe}^{2+} / \mathrm{TPTZ}^{2}$ complex in acidic $\mathrm{pH}$ by the action of an electron-donor antioxidant. Briefly, $25 \mathrm{~mL}$ of acetate buffer $(0.3$ M), $2.5 \mathrm{~mL}$ of an aqueous solution of TPTZ $(10 \mathrm{mM})$, and $2.5 \mathrm{~mL}$ of an aqueous solution of ferric chloride (20 mM) were mixed together to obtain the FRAP reagent. Then, $90 \mu \mathrm{L}$ of extract was mixed with $270 \mu \mathrm{L}$ of distilled water and $2.7 \mathrm{~mL}$ of FRAP reagent, vigorously homogenized, and kept at $37{ }^{\circ} \mathrm{C}$ for $30 \mathrm{~min}$. The change in absorbance was determined spectrophotometrically at $595 \mathrm{~nm}$. Antioxidant activity was calculated against a standard curve of ferrous sulfate $(2000 \mu \mathrm{M})$. Trolox $(800 \mu \mathrm{M})$ was used as a positive control (Thaipong et al., 2006). Experiments were performed in triplicate.

\section{Determination of total phenolic content}

For determination of total phenolics, crude extracts $(300 \mu \mathrm{L})$ were mixed with $2.5 \mathrm{~mL}$ of Folin-Ciocalteu 
reagent (10\% in water) and $2.0 \mathrm{~mL}$ of $\mathrm{Na}_{2} \mathrm{CO}_{3}(75 \mathrm{~g} / \mathrm{L})$, homogenized, and incubated at $50{ }^{\circ} \mathrm{C}$ for $15 \mathrm{~min}$.

Total phenolic content was calculated from a standard curve of gallic acid $(0,10,20,40,60,80$, and 100

$\mu \mathrm{g} / \mathrm{mL}$ ). Absorbance readings were taken at $740 \mathrm{~nm}$. Experiments were conducted in triplicate.

\section{Statistical analysis}

Differences between mean values were analyzed by the Scott-Knott test using Assistat version 7.7.

\section{Results}

\section{Isolation of endophytic fungi from B. uniflora}

Figure 1 shows the growth of endophytic fungi obtained from internal tissues of $B$. uniflora stems. Each fungus was isolated until a pure culture was obtained.

A total of 46 fungi were isolated from B. uniflora stems. Isolates were classified into 24 morphotypes according to morphological similarities (Table 1). The morphological traits analyzed were mycelium color, spore color, and color changes in the culture medium. Other early growth characteristics of mycelia were considered, such as shape, halo formation, outer edge growth, and specific traits.

Group 2 comprised the largest number of isolates (CE2A, CE2B, CE2C, CE2D, and CE2E), accounting for $11 \%$ of the fungi isolated from B. uniflora stems. Of the 46 fungi isolated from B. uniflora, 9 were classified according to conventional taxonomy as Nigrospora oryzae (CE1E and CE25), Nodulisporium sp. (CE11A), Phomopsis archeri (CE4A, CE8A, CE17, and CE24), and Penicillium sp. (CE19 and CE22), all of which are ascomycetes.

\section{Assessment of mycelial viability after cryopreservation}

All fungi cryopreserved on PDA or wheat grains with sucrose as cryoprotectant showed $100 \%$ mycelial viability after 6 months of cryopreservation at $-80^{\circ} \mathrm{C}$ (Table 2). Although PDA and wheat grains resulted in the same mycelial viability, there were differences in the time to onset of mycelial growth after thawing. For fungi maintained on PDA and cryopreserved for 1 month, the time to growth onset ranged from 18 to $42 \mathrm{~h}$, with a mean of $23 \mathrm{~h}$, whereas, for fungi maintained on wheat grains, the time to growth onset ranged from 12 to $24 \mathrm{~h}$, with a mean of $18 \mathrm{~h}$. Thus, after 1 month of cryopreservation, the time to onset of growth was shorter for fungi maintained on wheat grains. After 6 months of cryopreservation, the time to growth 
onset ranged from 18 to $23 \mathrm{~h}$ (mean of $21 \mathrm{~h}$ ) for fungi maintained on PDA and from 17 to $26 \mathrm{~h}$ (mean of $22 \mathrm{~h}$ ) for fungi maintained on wheat grains. These findings show that cryopreservation for up to 6 months at $-80^{\circ} \mathrm{C}$ is effective in maintaining mycelial viability.

\section{Cellulase activity}

All isolates showed mycelial growth on CMC medium (Table 3), demonstrating their ability to produce cellulase, as the only carbon source of the medium was CMC. The following isolates produced a noticeable halo outside the mycelial diameter: CE5A, CE7A, CE10A, CE12A, CE12B, CE15B, CE20, and CE23. Despite the morphological similarity of groups 5 (CE5A and CE5B), 10 (CE10A and CE10B), 12 (CE12A, CE12B, CE12C, CE12D, and CE12E), and 15 (CE15A and 15B), these fungi had different enzyme activities. Of the isolates of group 5 (CE5A and CE5B), only CE5A produced a halo; CE5B did not significantly alter medium color, as assessed by the Congo red dye method.

\section{Laccase activity}

Laccase was produced by eight fungi (Figure 2). CE23 differed from the other isolates in laccase activity from the fifth to the ninth day of culture. The highest laccase activity was $1.071 \mathrm{U} / \mathrm{mL}$, detected in CE23 on the seventh day of culture. CE5A, CE7A, CE10A, CE12A, CE12B, CE15B, and CE20 did not show significant enzyme activity (Table 4).

\section{Antioxidant activity}

After screening for $\mathrm{DPPH} \bullet$ scavenging activity, 12 isolates (CE1E, CE11A, CE12B, CE14A, CE14B, CE15B, CE18, CE19, CE21, CE22, CE23, and CE24) were selected for determination of IC50, FRAP, and total phenolic content (Table 5).

The lowest $D P P H \bullet \mathrm{IC}_{50}$ values were observed for CE14A $(15.049 \pm 0.017 \mathrm{mg} / \mathrm{mL}), \mathrm{CE} 19(15.716$ $\pm 0.393 \mathrm{mg} / \mathrm{mL}), \mathrm{CE} 24(15.818 \pm 0.327 \mathrm{mg} / \mathrm{mL}), \mathrm{CE} 15 \mathrm{~B}(17.122 \pm 1.054 \mathrm{mg} / \mathrm{mL}), \mathrm{CE} 18(18.281 \pm 0.386$ $\mathrm{mg} / \mathrm{mL})$, and CE22 $(20.776 \pm 1.503 \mathrm{mg} / \mathrm{mL})$. The $\mathrm{IC}_{50}$ values of the other isolates ranged from $29.240 \pm$ 1.832 to $43.055 \pm 5.830 \mathrm{mg} / \mathrm{mL}$. The $D P P H \bullet \mathrm{IC}_{50}$ of isolates was $485-670$ times higher than that of the positive control quercetin $\left(\mathrm{IC}_{50}=0.031 \pm 0.002 \mathrm{mg} / \mathrm{mL}\right)$, showing that the endophytes had a low $D P P H \bullet$ scavenging activity. Ascêncio et al. (2014) observed significant $D P P H \bullet\left(\mathrm{IC}_{50}\right)$ activity in 5 of the 13 endophytic fungi isolated from Costus spiralis; Cochliobolus spp. had an $\mathrm{IC}_{50}$ of $0.189 \mathrm{mg} / \mathrm{mL}$, higher 
than that observed here for B. uniflora endophytic fungi.

CE14A had the highest FRAP activity $\left(0.061 \pm 0.001 \mu \mathrm{M} \mathrm{Fe} \mathrm{SO}_{4} / \mathrm{mg}\right)$ and total phenolic content $(55.296 \pm 3.536 \mu \mathrm{g} / \mathrm{mg})$. Higher FRAP activities were reported by Ascêncio et al. (2014) for endophytic fungi (133.74 \pm 0.29 to $471.15 \pm 2.87 \mu \mathrm{M} \mathrm{Fe} \mathrm{SO}_{4} / \mathrm{mg}$ ). Mahdi et al. (2014) identified a total phenolic content of $8300 \mu \mathrm{g} / \mathrm{mg}$ in Aspergillus sp. isolated from stems of D. stramonium. Thus, fungi isolated from B. uniflora in the current study had lower antioxidant activity and total phenolic content than other endophytes reported in the literature.

\section{Discussion}

There are no reports of endophytic fungal diversity in B. uniflora. Mahdi et al. (2014) isolated five endophytic fungi from stems of Datura stramonium (Solanaceae). According to Nath et al. (2012), endophytic fungal diversity is greatest in plant stems. The authors isolated 11 fungi from different parts of Emblica officinalis (Phyllanthaceae), and 5 were obtained from the stem.

The most frequent endophytic fungi of Tephrosia purpurea belonged to the genera Nigrospora (14.7\%) and Penicillium (9.8\%) (Luo et al., 2015). The genus Phomopsis represented $46 \%$ of the isolates obtained from Picea sitchensis (Carroll \& Carroll, 1978). Costa et al. (2012) found that Nodulisporium individuals accounted for $4 \%$ of the endophytic fungi isolated from Rhizophora mangle (Rhizophoraceae) and Laguncularia racemosa (Combretaceae).

Nigrospora was found to synthesize the bioactive compound anthraquinone (deoxybostrycin), effective against cancer cells (Xia et al., 2011). Penicillium, the widely known producer of penicillin (Demain \& Elander, 1999), also produces mycotoxins (Frisvad et al., 2004) and compounds with anticholesterolemic (Chakravarti \& Sahai, 2004) and antitumor action (Nicoletti et al., 2008). Phomopsis was shown to exert antifungal and antibiotic activities and produce volatile organic compounds such as sabinene (S. K. Singh et al., 2011). The endophytic fungus Nodulisporium sp. isolated from Juniperus cedrus (Cupressaceae) produced the antibacterial compounds 1-(2,6-dihydroxyphenyl)butan-1-one, nodulisporin D and F, and benzene-1,2,3-triol (Dai et al., 2006, 2009). These findings suggest that the highly diverse endophytic microbiota of $B$. uniflora is a potential source of biologically active compounds. 
sucrose at 50,100 , or $300 \mathrm{~g} \mathrm{~L}^{-1}$ for one year was effective in preserving $100 \%$ of mycelial viability. Cereal grains are rich in starch reserves, providing a nutrient-rich medium. Furthermore, the capillary structure of wheat grain seems to contribute greatly to mycelial recovery after cryopreservation. The capillary network of cereal grains provides little physical space for water molecules, protecting mycelia from ice formation (Tanaka et al., 2013). The large amount of carbohydrates and proteins that bind to water (Belitz \& Grosch, 1997) might be responsible for the reduction in free water and ice crystal formation, minimizing the risk of cryoinjury. Thus, whole wheat grains, which have been successfully used for the cryopreservation of basidiomycetes (Basidiomycota), might be better than PDA medium for long-term cryopreservation of endophytic fungi (Ascomycota) isolated from B. uniflora. Future studies investigating longer cryopreservation times are needed to better assess the effect of wheat grains on ascomycete cryopreservation.

Ngieng et al. (2013) reported that $65 \%$ of the 20 endophytic fungi isolated from Melastoma malabathricum (Melastomataceae) exhibited cellulase activity as assessed by a qualitative test. Patil et al. (2015) found that, of the nine fungi isolated from medicinal plants in India, including Azadirachta indica, Citrus limon, Gossypium hirsutum, Magnolia champaca, D. stramonium, Piper betle, and Phyllanthus emblica, 44\% exhibited qualitative cellulase activity. Similarly, using a qualitative test, Yasser et al. (2019) found that $63 \%$ of the 19 endophytic fungi of Solanum tuberosum had cellulase activity and $31 \%$ showed laccase activity. In our study, only $17 \%$ of fungi were positive for cellulase, despite the observed fungal diversity and enzyme and secondary metabolite production.

Urairuj (2003) found that the maximum laccase activity $(0.01 \mathrm{U} / \mathrm{mL})$ of Xylaria sp. isolated from plants native to Thailand occurred on the seventh day of culture. In the study of Wang et al. (2006), Monotospora sp. isolated from the plant Cynodon dactylon had a maximum laccase activity of $3.49 \mathrm{U} / \mathrm{mL}$ on the eighth day of culture. Under controlled conditions of $\mathrm{pH}$, temperature, and carbon and nitrogen sources, Monotospora sp. was found to have an activity of $13.55 \mathrm{U} / \mathrm{mL}$, higher than that observed in the current study for $B$. uniflora endophytes $(1.071 \mathrm{U} / \mathrm{mL}$ in CE23). The laccase activity of $B$. uniflora endophytic fungi was lower than that of other endophytes reported in the literature. However, it should be noted that enzyme production may be optimized. 
It is important to evaluate antioxidant activity using other types of extracts. In a previous study, our research group obtained the oleoresin of leaves and flowers of $B$. uniflora by carbon dioxide $\left(\mathrm{CO}_{2}\right)$ extraction at 40,50 , and $60{ }^{\circ} \mathrm{C}$ and 150,175 , and 200 bar. Leaf oleoresin obtained at $60{ }^{\circ} \mathrm{C}$ and 150 bar showed the highest $D P P H \bullet\left(\mathrm{IC}_{50}=1.90 \mathrm{mg} / \mathrm{mL}\right)$ and FRAP $(1.8 \mu \mathrm{M} / \mathrm{mL})$ activities. These samples also had the highest total phenolic content (66.20-83.33 $\mu \mathrm{g}$ gallic acid equivalents/mg) and oxidation inhibition potential (120.94-124.14\%), as assessed by the $\beta$-carotene/linoleic acid assay at $40-60{ }^{\circ} \mathrm{C}$ and $150-200$ bar (Jorge et al., 2017). In the present study, however, the 12 fungal extracts had low total phenolic, $D P P H \bullet$, and FRAP values. It is essential that more than one extractive method be used to assert the biological potential of fungi and that the chosen antioxidant assay be compatible with the isolated active compounds.

\section{Conclusions}

B. uniflora stems harbor a great diversity of endophytic fungi. These fungi showed mycelial viability after 1 and 6 months of cryopreservation at $-80^{\circ} \mathrm{C}$ as well as significant cellulase and laccase activities. Twelve isolates exhibited low $D P P H \bullet$ scavenging activities, FRAP activities, and total phenolic contents.

\section{Referências}

Ascêncio, M. P. G., Ascêncio, S. D., Aguiar, A. A., Fiorini, A., \& Pimenta, R. S. (2014). Chemical Assessment and Antimicrobial and Antioxidant Activities of Endophytic Fungi Extracts Isolated from Costus spiralis (Jacq.) Roscoe (Costaceae). Evidence-Based Complementary and Alternative Medicine, 2014, 1-10. https://doi.org/10.1155/2014/190543

Barnett, H. L., \& Hunter, B. B. (1986). Illustrated Genera of Imperfect Fungi (4th ed.). Macmillan Publishing Co.

Belitz, H. D., \& Grosch, W. (1997). Food Chemistry. Acribia.

Benzie, I. F. F., \& Strain, J. J. (1996). The Ferric Reducing Ability of Plasma (FRAP) as a Measure of "Antioxidant Power": The FRAP Assay. Analytical Biochemistry, 239(1), 70-76. https://doi.org/10.1006/abio.1996.0292

Brand-Williams, W., Cuvelier, M. E., \& Berset, C. (1995). Use of a free radical method to evaluate antioxidant activity. LWT - Food Science and Technology, 28(1), 25-30. https://doi.org/10.1016/S0023-6438(95)80008-5

Brunner, G., Burger, U., Castioni, P., Kapetanidis, I., \& Christen, P. (2000). A novel acylated flavonol glycoside isolated from Brunfelsia grandiflora ssp. grandiflora. Structure elucidation by gradient accelerated NMR spectroscopy at 14T. Phytochemical Analysis - PHYTOCHEM ANALYSIS, 11, 2933. https://doi.org/10.1002/(SICI)1099-1565(200001/02)11:13.0.CO;2-K

Cardoso, B. K., Linde, G. A., Colauto, N. B., \& do Valle, J. S. (2018). Panus strigellus laccase decolorizes anthraquinone, azo, and triphenylmethane dyes. Biocatalysis and Agricultural Biotechnology, 16, 558-563. https://doi.org/10.1016/j.bcab.2018.09.026 
Carroll, G. C., \& Carroll, F. E. (1978). Studies on the incidence of coniferous needle endophytes in the Pacific Northwest. Canadian Journal of Botany, 56(24), 3034-3043. https://doi.org/10.1139/b78-367

Castioni, P., \& Kapetanidis, I. (1996). Volatile constituents from Brunfelsia grandiflora ssp. grandiflora: qualitative analysis by GC-MS. Scientia Pharmaceutica, 64, 83-91.

Chakravarti, R., \& Sahai, V. (2004). Compactin: a review. Applied Microbiology and Biotechnology, 64(5), 618-624. https://doi.org/10.1007/s00253-003-1553-7

Challen, M. P., \& Elliot, T. J. (1986). Polypropylene straw ampoules for the storage of microorganisms in liquid nitrogen. Journal of Microbiological Methods, 5(1), 11-22. https://doi.org/10.1016/01677012(86)90019-9

Colauto, N. B., Cordeiro, F. A., Geromini, K. V. N., de Lima, T. G., Lopes, A. D., Nunes, R. A. R., de Brito Roratto, F., Tanaka, H. S., Zaghi, L. L., \& Linde, G. A. (2012). Viability of Agaricus blazei after long-term cryopreservation. Annals of Microbiology, 62(2), 871-876. https://doi.org/10.1007/s13213-011-0368-5

Colauto, N. B., da Eira, A. F., \& Linde, G. A. (2011). Cryopreservation at $-80^{\circ} \mathrm{C}$ of Agaricus blazei on rice grains. World Journal of Microbiology and Biotechnology, 27(12), 3015-3018. https://doi.org/10.1007/s11274-011-0772-9

Colauto, N. B., Da Eira, A. F., \& Linde, G. A. (2012). Cryopreservation of agaricus blazei in liquid nitrogen using dmso as cryoprotectant. Bioscience Journal, 28(6), 1034-1037.

Compant, S., Clément, C., \& Sessitsch, A. (2010). Plant growth-promoting bacteria in the rhizo- and endosphere of plants: Their role, colonization, mechanisms involved and prospects for utilization. Soil Biology and Biochemistry, 42(5), 669-678. https://doi.org/10.1016/j.soilbio.2009.11.024

Costa, I. P. M. W., Maia, L. C., \& Cavalcanti, M. A. (2012). Diversity of leaf endophytic fungi in mangrove plants of northeast Brazil. Brazilian Journal of Microbiology, 43(3), 1165-1173.

Dai, J., Krohn, K., Draeger, S., \& Schulz, B. (2009). New Naphthalene-Chroman Coupling Products from the Endophytic Fungus, Nodulisporium sp. from Erica arborea. European Journal of Organic Chemistry, 2009(10), 1564-1569. https://doi.org/10.1002/ejoc.200801106

Dai, J., Krohn, K., Flörke, U., Draeger, S., Schulz, B., Kiss-Szikszai, A., Antus, S., Kurtán, T., \& van Ree, T. (2006). Metabolites from the Endophytic FungusNodulisporium sp. fromJuniperus cedre. European Journal of Organic Chemistry, 2006(15), 3498-3506. https://doi.org/10.1002/ejoc.200600261

Davitt, A. J., Chen, C., \& Rudgers, J. A. (2011). Understanding context-dependency in plant-microbe symbiosis: The influence of abiotic and biotic contexts on host fitness and the rate of symbiont transmission. Environmental and Experimental Botany, 71(2), 137-145. https://doi.org/10.1016/j.envexpbot.2010.11.004

Demain, A. L., \& Elander, R. P. (1999). The beta-lactam antibiotics: past, present, and future. Antonie Van Leeuwenhoe, 75(1-2), 5-19.

Domsch, K. H., Gams, W., \& Anderson, T.-H. (2008). Compendium of Soil Fungi. European Journal of Soil Science, 59(5), 1007-1007. https://doi.org/10.1111/j.1365-2389.2008.01052_1.x

Frisvad, J., Smedsgaard, J., Larsen, T. O., \& Samson, R. (2004). Mycotoxins and other extrolites produced by species in Penicillium subgenus Penicillium. Studies in Mycology, 2004, 201-241.

Gunatilaka, A. A. L. (2006). Natural Products from Plant-Associated Microorganisms: Distribution, Structural Diversity, Bioactivity, and Implications of Their Occurrence $\perp$. Journal of Natural Products, 69(3), 509-526. https://doi.org/10.1021/np058128n

Gundel, P. E., Garibaldi, L. A., Martínez-Ghersa, M. A., \& Ghersa, C. M. (2011). Neotyphodium endophyte transmission to Lolium multiflorum seeds depends on the host plant fitness. Environmental and Experimental Botany, 71(3), 359-366. https://doi.org/10.1016/j.envexpbot.2011.02.002

Guo, B., Wang, Y., Sun, X., \& Tang, K. (2008). Bioactive natural products from endophytes: A review. Applied Biochemistry and Microbiology, 44(2), 136-142. https://doi.org/10.1134/S0003683808020026

Hardoim, P. R., van Overbeek, L. S., \& Elsas, J. D. van. (2008). Properties of bacterial endophytes and their proposed role in plant growth. Trends in Microbiology, 16(10), 463-471. https://doi.org/10.1016/j.tim.2008.07.008 
Harper, J. K., Arif, A. M., Ford, E. J., Strobel, G. A., Porco, J. A., Tomer, D. P., Oneill, K. L., Heider, E. M., \& Grant, D. M. (2003). Pestacin: a 1,3-dihydro isobenzofuran from Pestalotiopsis microspora possessing antioxidant and antimycotic activities. Tetrahedron, 59(14), 2471-2476. https://doi.org/10.1016/S0040-4020(03)00255-2

Homolka, L., Lisá, L., \& Nerud, F. (2003). Viability of basidiomycete strains after cryopreservation: Comparison of two different freezing protocols. Folia Microbiologica, 48(2), 219-226. https://doi.org/10.1007/BF02930959

Humber, R. A. (1997). Fungi: Preservation of cultures. In Manual of Techniques in Insect Pathology (pp. 269-279). Elsevier. https://doi.org/10.1016/B978-012432555-5/50015-4

Ito, T., \& Nakagiri, A. (1996). Viability of frozen cultures of basidiomycetes after fifteen-year storage. . . Microbiology and Culture Collection, 1, 67-68.

Jalgaonwala, R., Mohite, B., \& Mahajan, R. (2011). A review: Natural products from plant associated endophytic fungi. J. Microbiol. Biotech. Res., 1, 21-32.

Kirk, P. M., \& Cooper, J. (2005). Index Fungorum - Authors of Fungal Names. IOP Publishing Physics.

Kour, A., Shawl, A. S., Rehman, S., Sultan, P., Qazi, P. H., Suden, P., Khajuria, R. K., \& Verma, V. (2008). Isolation and identification of an endophytic strain of Fusarium oxysporum producing podophyllotoxin from Juniperus recurva. World Journal of Microbiology and Biotechnology, 24(7), 1115-1121. https://doi.org/10.1007/s11274-007-9582-5

Luo, Z.-P., Lin, H.-Y., Ding, W.-B., He, H.-L., \& Li, Y.-Z. (2015). Phylogenetic Diversity and Antifungal Activity of Endophytic Fungi Associated with Tephrosia purpurea. Mycobiology, 43(4), 435-443. https://doi.org/10.5941/MYCO.2015.43.4.435

Mahdi, T., Mohamed, I., \& Yagi, S. (2014). Endophytic Fungal Communities Associated with Ethnomedicinal Plants from Sudan and their Antimicrobial and Antioxidant Prospective. JOURNAL OF FOREST PRODUCTS \& INDUSTRIES, 3, 248-256.

Mantovani, T. R. D. (2008). Cryopreservation of genus Pleurotus at $-20{ }^{\circ} \mathrm{C}$ and $-70{ }^{\circ} \mathrm{C}$. Arquivo de Ciências Veterinárias e Zoologia Da Unipar, 1, 107-112.

Mejía, L. C., Rojas, E. I., Maynard, Z., Bael, S. Van, Arnold, A. E., Hebbar, P., Samuels, G. J., Robbins, N., \& Herre, E. A. (2008). Endophytic fungi as biocontrol agents of Theobroma cacao pathogens. Biological Control, 46(1), 4-14. https://doi.org/10.1016/j.biocontrol.2008.01.012

Molyneux, P. (2004). The use of the stable radical Diphenylpicrylhydrazyl (DPPH) for estimating antioxidant activity. Journal of ScienceeTechnology, 26, 211-219.

Mors, W., \& Ribeiro, O. (1957). Notes - Occurnece of Scopoletin in the Genus Brunfelia. The Journal of Organic Chemistry, 22(8), 978-979. https://doi.org/10.1021/jo01359a601

Nath, A., Raghunatha, P., \& Joshi, S. R. (2012). Diversity and Biological Activities of Endophytic Fungi of Emblica officinalis, an Ethnomedicinal Plant of India. Mycobiology, 40(1), 8-13. https://doi.org/10.5941/MYCO.2012.40.1.008

Ngieng, N. S., Zulkharnain, A., Roslan, H. A., \& Husaini, A. (2013). Decolourisation of Synthetic Dyes by Endophytic Fungal Flora Isolated from Senduduk Plant ( Melastoma malabathricum ). ISRN Biotechnology, 2013, 1-7. https://doi.org/10.5402/2013/260730

Nicoletti, R., Ciavatta, M., Buommino, E., \& Tufano, M. (2008). Antitumor extrolites produced by Penicillium species. Int. J. Biomed. Pharm. Sci, 2(1), 1-23.

Patil, M. G., Pagare, J., Patil, S. N., \& Sidhu, A. K. (2015). Extracellular Enzymatic Activities of Endophytic Fungi Isolated from Various Medicinal Plants. Int.J.Curr.Microbiol.App.Sci, 4(3), 10351042.

Pereira, J. O., Azevedo, J. L., \& Petrini, O. (1993). Endophytic Fungi of Stylosanthes: A First Report. Mycologia, 85(3), 362. https://doi.org/10.2307/3760696

Petrini, O. (1991). Fungal Endophytes of Tree Leaves BT - Microbial Ecology of Leaves (J. H. Andrews \& S. S. Hirano (eds.); pp. 179-197). Springer New York.

Pontecorvo, G., Roper, J. A., Chemmons, L. M., Macdonald, K. D., \& Bufton, A. W. J. (1953). The Genetics of Aspergillus nidulans. Advances in Genetics, 5(1953), 141-238. https://doi.org/10.1016/S0065-2660(08)60408-3

Riddell, R. W. (1950). Permanent Stained Mycological Preparations Obtained by Slide Culture. Mycologia, 42(2), 265. https://doi.org/10.2307/3755439 
Ruppelt, B. M., Pereira, E. F. R., Gonçalves, L. C., \& Pereira, N. A. (1991). Pharmacological screening of plants recommended by folk medicine as anti-snake venom: I. Analgesic and anti-inflammatory activities. Memórias Do Instituto Oswaldo Cruz, 86(suppl 2), 203-205. https://doi.org/10.1590/S0074-02761991000600046

Saikkonen, K. (2007). Forest structure and fungal endophytes. Fungal Biology Reviews, 21(2-3), 67-74. https://doi.org/10.1016/j.fbr.2007.05.001

Schultes, R. E. (2018). Solanaceous hallucinogens and their role in the development of new world cultures. In J. G. Hawkes, R. N. Lester, \& A. D. Skelding (Eds.), The biology and taxonomy of the Solanaceae (p. 738). Dep. of Pl. Biol.

Sharma, B., Dangi, A. K., \& Shukla, P. (2018). Contemporary enzyme based technologies for bioremediation: A review. Journal of Environmental Management, 210, 10-22. https://doi.org/10.1016/j.jenvman.2017.12.075

Shin, S. K., Hyeon, J. E., Joo, Y.-C., Jeong, D. W., You, S. K., \& Han, S. O. (2019). Effective melanin degradation by a synergistic laccase-peroxidase enzyme complex for skin whitening and other practical applications. International Journal of Biological Macromolecules, 129, 181-186. https://doi.org/10.1016/j.ijbiomac.2019.02.027

Singh, A., Bajar, S., Devi, A., \& Pant, D. (2021). An overview on the recent developments in fungal cellulase production and their industrial applications. Bioresource Technology Reports, 14, 100652. https://doi.org/10.1016/j.biteb.2021.100652

Singh, G., \& Arya, S. K. (2019). Utility of laccase in pulp and paper industry: A progressive step towards the green technology. International Journal of Biological Macromolecules, 134, 1070-1084. https://doi.org/10.1016/j.ijbiomac.2019.05.168

Singh, S. K., Strobel, G. A., Knighton, B., Geary, B., Sears, J., \& Ezra, D. (2011). An Endophytic Phomopsis sp. Possessing Bioactivity and Fuel Potential with its Volatile Organic Compounds. Microbial Ecology, 61(4), 729-739. https://doi.org/10.1007/s00248-011-9818-7

Strobel, G., \& Daisy, B. (2003). Bioprospecting for Microbial Endophytes and Their Natural Products. Microbiology and Molecular Biology Reviews, 67(4), 491-502. https://doi.org/10.1128/MMBR.67.4.491-502.2003

Strobel, G., Ford, E., Worapong, J., Harper, J. K., Arif, A. M., Grant, D. M., Fung, P. C. W., \& Ming Wah Chau, R. (2002). Isopestacin, an isobenzofuranone from Pestalotiopsis microspora, possessing antifungal and antioxidant activities. Phytochemistry, 60(2), 179-183. https://doi.org/10.1016/S0031-9422(02)00062-6

Sun, L., Qiu, F., Zhang, X., Dai, X., Dong, X., \& Song, W. (2008). Endophytic Bacterial Diversity in Rice (Oryza sativa L.) Roots Estimated by 16S rDNA Sequence Analysis. Microbial Ecology, 55(3), 415424. https://doi.org/10.1007/s00248-007-9287-1

Sunitha, V. H., Devi, D. N., \& Srinivas, C. (2013). Extracellular Enzymatic Activity of Endophytic Fungal Strains Isolated from Medicinal Plants. World Journal of Agricultural Sciences, 9(1), 1-9. https://doi.org/10.5829/idosi.wjas.2013.9.1.72148

Sutton, B. C. (1980). The Coelomycetes. Commonwealth Mycological Institute.

Tanaka, H. S., Mantovani, T. R. D. A., Santos, M. P. dos, Linde, G. A., \& Colauto, N. B. (2013). Cereal grains and glycerol in Agaricus blazei cryopreservation. Bioscience Journal, 29(3), 627-633.

Thaipong, K., Boonprakob, U., Crosby, K., Cisneros-Zevallos, L., \& Hawkins Byrne, D. (2006). Comparison of ABTS, DPPH, FRAP, and ORAC assays for estimating antioxidant activity from guava fruit extracts. Journal of Food Composition and Analysis, 19(6-7), 669-675. https://doi.org/10.1016/j.jfca.2006.01.003

Wang, J. W., Wu, J. H., Huang, W. Y., \& Tan, R. X. (2006). Laccase production by Monotospora sp., an endophytic fungus in Cynodon dactylon. Bioresource Technology, 97(5), 786-789. https://doi.org/10.1016/j.biortech.2005.03.025

Xia, X., Li, Q., Li, J., Shao, C., Zhang, J., Zhang, Y., Liu, X., Lin, Y., Liu, C., \& She, Z. (2011). Two New Derivatives of Griseofulvin from the Mangrove Endophytic Fungus Nigrospora sp. (Strain No. 1403) from Kandelia candel (L.) Druce. Planta Medica, 77(15), 1735-1738. https://doi.org/10.1055/s0030-1271040

Yang, S., Yang, B., Duan, C., Fuller, D. A., Wang, X., Chowdhury, S. P., Stavik, J., Zhang, H., \& Ni, Y. 
(2019). Applications of enzymatic technologies to the production of high-quality dissolving pulp: A review. Bioresource Technology, 281, 440-448. https://doi.org/10.1016/j.biortech.2019.02.132

Yasser, M. M., Mousa, A. S. M., Marzouk Marym, A., \& Tagyan, A. I. (2019). Molecular Identification, Extracellular Enzyme Production and Antimicrobial Activity of Endophytic Fungi Isolated from Solanum tuberosum L. in Egypt. Biosciences, Biotechnology Research Asia, 16(1), 135-142. https://doi.org/10.13005/bbra/2731

Zhao, J. (2010). Endophytic fungi for producing bioactive compounds originally from their host plants. In A. Mendez-Vilas (Ed.), Current research, technology and education topics in applied microbiology and microbial biotechnology (2nd ed., pp. 567-576). Formatex Research Center. 


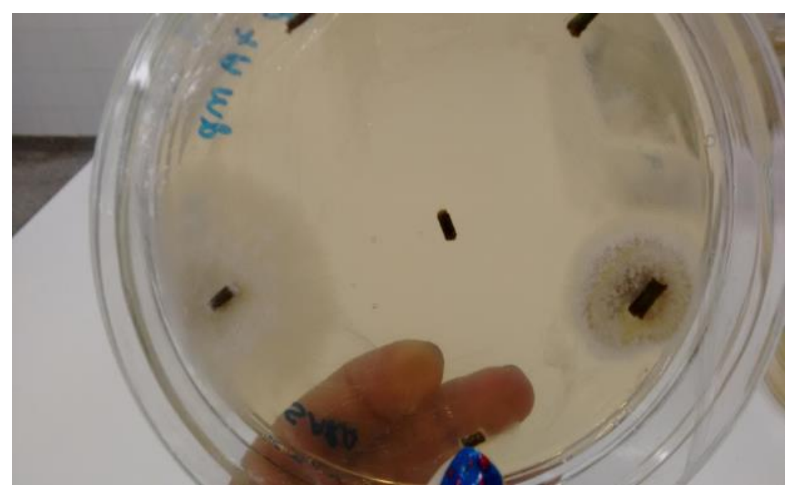

Figure 1. Growth of fungi from Brunfelsia uniflora stem fragments. 


\begin{tabular}{|c|c|c|c|c|c|c|}
\hline Group & Isolate & Morphology & Morphotype & $(\%)$ & Colony characteristics and photomicrographs & Initial identification \\
\hline 1 & 4 & $\begin{array}{c}\text { Black and white mycelium, } \\
\text { black spores, black growth } \\
\text { medium }\end{array}$ & $\begin{array}{c}\text { CE1A, CE1B, CE1C, } \\
\text { CE1E }\end{array}$ & 9 & & $\begin{array}{c}\mathrm{CE} 1 \mathrm{E}=\text { Nigrospora } \\
\text { oryzae (Ascomycota) }\end{array}$ \\
\hline 2 & 5 & $\begin{array}{l}\text { White mycelium, black } \\
\text { spores, growth medium with } \\
\text { a brown halo }\end{array}$ & $\begin{array}{c}\text { CE2A, CE2B, CE2C, } \\
\text { CE2D, CE2E }\end{array}$ & 11 & & Not identified \\
\hline 3 & 3 & $\begin{array}{l}\text { White mycelium, black } \\
\text { spores, growth medium with } \\
\text { a yellow halo }\end{array}$ & CE3A, CE3B, CE3C, & 7 & & Not identified \\
\hline 4 & 4 & $\begin{array}{l}\text { White and yellow } \\
\text { mycelium, brown spores, } \\
\text { light yellow growth medium }\end{array}$ & $\begin{array}{c}\text { CE4A, CE4B, CE4C, } \\
\text { CE4D }\end{array}$ & 9 & & $\begin{array}{c}\text { CE4A = Phomopsis } \\
\text { archeri (Ascomycota) }\end{array}$ \\
\hline 5 & 2 & $\begin{array}{c}\text { White and gray mycelium, } \\
\text { brown spores, light yellow } \\
\text { growth medium with a dark } \\
\text { brown halo }\end{array}$ & CE5A, CE5B & 4 & & Not identified \\
\hline 6 & 1 & $\begin{array}{l}\text { White mycelium with a } \\
\text { yellow center, black spores, } \\
\text { no color changes in the } \\
\text { growth medium }\end{array}$ & CE6A & 2 & & Not identified \\
\hline 7 & 2 & $\begin{array}{c}\text { Yellow and white } \\
\text { mycelium, dark yellow } \\
\text { spores, yellow growth } \\
\text { medium with a brown halo }\end{array}$ & CE7A, CE7B & 4 & & Not identified \\
\hline 8 & 2 & $\begin{array}{c}\text { White and brown mycelium, } \\
\text { black spores, brown growth } \\
\text { medium }\end{array}$ & CE8A, CE8B & 4 & & $\begin{array}{c}\text { CE8A = Phomopsis } \\
\text { archeri (Ascomycota) }\end{array}$ \\
\hline
\end{tabular}




\begin{tabular}{|c|c|c|c|c|c|c|}
\hline Group & Isolate & Morphology & Morphotype & $(\%)$ & Colony characteristics and photomicrographs & Initial identification \\
\hline 9 & 1 & $\begin{array}{l}\text { White mycelium, brown } \\
\text { spores, growth medium with } \\
\text { a brown halo }\end{array}$ & CE9A & 2 & & Not identified \\
\hline 10 & 2 & $\begin{array}{l}\text { White and gray mycelium, } \\
\text { black spores, yellow growth } \\
\text { medium with a brown halo }\end{array}$ & CE10A, CE10B & 4 & & Not identified \\
\hline 11 & 1 & $\begin{array}{l}\text { White and gray mycelium, } \\
\text { black spores, dark gray } \\
\text { growth medium }\end{array}$ & CE11A & 2 & & $\begin{array}{c}\text { CE11A = } \\
\text { Nodulisporium sp. } \\
\text { (Ascomycota) }\end{array}$ \\
\hline 12 & 3 & $\begin{array}{l}\text { White and yellow } \\
\text { mycelium, yellow spores, } \\
\text { yellow growth medium }\end{array}$ & $\begin{array}{c}\text { CE12A, CE12B } \\
\text { CE12C }\end{array}$ & 7 & & Not identified \\
\hline 13 & 2 & $\begin{array}{l}\text { White and brown mycelium, } \\
\text { black spores, growth } \\
\text { medium with a yellow halo }\end{array}$ & CE13A, CE13B & 4 & & Not identified \\
\hline 14 & 3 & $\begin{array}{l}\text { White mycelium, white } \\
\text { spores, growth medium with } \\
\text { a yellow halo }\end{array}$ & $\begin{array}{l}\text { CE14A, CE14B, } \\
\text { CE14C }\end{array}$ & 7 & & Not identified \\
\hline 15 & 2 & $\begin{array}{l}\text { White and brown mycelium, } \\
\text { brown spores, growth } \\
\text { medium with a brown halo }\end{array}$ & CE15A, CE15B & 4 & & Not identified \\
\hline 17 & 1 & $\begin{array}{l}\text { Brown and yellow } \\
\text { mycelium, brown spores, no } \\
\text { color changes in the growth } \\
\text { medium }\end{array}$ & CE17 & 2 & & $\begin{array}{c}\text { CE17 = Phomopsis } \\
\text { archeri (Ascomycota) }\end{array}$ \\
\hline
\end{tabular}




\begin{tabular}{|c|c|c|c|c|c|c|}
\hline Group & Isolate & Morphology & Morphotype & $(\%)$ & Colony characteristics and photomicrographs & Initial identification \\
\hline 18 & 1 & $\begin{array}{l}\text { Brown mycelium, brown } \\
\text { spores, dark brown growth } \\
\text { medium }\end{array}$ & CE18 & 2 & & Not identified \\
\hline 19 & 1 & $\begin{array}{l}\text { White and yellow } \\
\text { mycelium, brown spores, } \\
\text { yellow growth medium with } \\
\text { a brown halo }\end{array}$ & CE19 & 2 & & $\begin{array}{c}\text { CE19 = Penicillium sp. } \\
\text { (Ascomycota) }\end{array}$ \\
\hline 20 & 1 & $\begin{array}{l}\text { White mycelium with } \\
\text { cottony texture, white } \\
\text { spores, no color changes in } \\
\text { the growth medium }\end{array}$ & CE20 & 2 & & Not identified \\
\hline 21 & 1 & $\begin{array}{l}\text { White mycelium, black } \\
\text { spores, yellow growth } \\
\text { medium with a light yellow } \\
\text { halo }\end{array}$ & CE21 & 2 & & Not identified \\
\hline 22 & 1 & $\begin{array}{c}\text { Yellow and white } \\
\text { mycelium, yellow dark } \\
\text { spores, yellow growth } \\
\text { medium with a dark brown } \\
\text { halo }\end{array}$ & CE22 & 2 & & $\begin{array}{l}\text { CE22 = Penicillium sp. } \\
\text { (Ascomycota) }\end{array}$ \\
\hline 23 & 1 & $\begin{array}{l}\text { White and yellow } \\
\text { mycelium, black spores, no } \\
\text { color changes in the growth } \\
\text { medium }\end{array}$ & CE23 & 2 & & Not identified \\
\hline 24 & 1 & $\begin{array}{l}\text { White mycelium with a } \\
\text { yellow center, black spores, } \\
\text { growth medium with a } \\
\text { brown halo }\end{array}$ & CE24 & 2 & & $\begin{array}{c}\text { CE24 = Phomopsis } \\
\text { archeri (Ascomycota) }\end{array}$ \\
\hline 25 & 1 & $\begin{array}{l}\text { White mycelium, black } \\
\text { spores, brown growth } \\
\text { medium }\end{array}$ & CE25 & 2 & & $\begin{array}{l}\text { CE25 = Nigrospora } \\
\text { oryzae (Ascomycota) }\end{array}$ \\
\hline
\end{tabular}


Table 2. Mycelial viability (MV) and time to onset of growth (TOG) of endophytic fungi isolated from Brunfelsia uniflora stems and cryopreserved at $-80^{\circ} \mathrm{C}$ using $1.5 \mathrm{~g} \mathrm{~L}^{-1}$ sucrose as cryoprotectant.

\begin{tabular}{|c|c|c|c|c|c|c|c|c|}
\hline \multirow{3}{*}{ Morphotype } & \multicolumn{4}{|c|}{ Potato dextrose agar } & \multicolumn{4}{|c|}{ Whole wheat grain } \\
\hline & \multicolumn{2}{|c|}{ 1-month cryopreservation } & \multicolumn{2}{|c|}{ 6-month cryopreservation } & \multicolumn{2}{|c|}{ 1-month cryopreservation } & \multicolumn{2}{|c|}{ 6-month cryopreservation } \\
\hline & MV (\%) & TOG $(\mathrm{h})$ & MV (\%) & TOG (h) & MV $(\%)$ & TOG (h) & MV (\%) & TOG (h) \\
\hline CE1A & 100 & 22 & 100 & 22 & 100 & 13 & 100 & 24 \\
\hline CE1B & 100 & 25 & 100 & 22 & 100 & 13 & 100 & 23 \\
\hline CE1C & 100 & 22 & 100 & 22 & 100 & 12 & 100 & 23 \\
\hline CE1E & 100 & 22 & 100 & 22 & 100 & 12 & 100 & 23 \\
\hline CE2A & 100 & 17 & 100 & 22 & 100 & 18 & 100 & 18 \\
\hline CE2B & 100 & 22 & 100 & 22 & 100 & 17 & 100 & 17 \\
\hline CE2C & 100 & 22 & 100 & 22 & 100 & 17 & 100 & 17 \\
\hline CE2D & 100 & 31 & 100 & 21 & 100 & 17 & 100 & 17 \\
\hline CE2E & 100 & 16 & 100 & 21 & 100 & 18 & 100 & 18 \\
\hline CE3A & 100 & 16 & 100 & 23 & 100 & 18 & 100 & 18 \\
\hline CE3B & 100 & 18 & 100 & 18 & 100 & 18 & 100 & 18 \\
\hline CE3C & 100 & 27 & 100 & 18 & 100 & 18 & 100 & 18 \\
\hline CE4A & 100 & 27 & 100 & 21 & 100 & 19 & 100 & 20 \\
\hline CE4B & 100 & 22 & 100 & 21 & 100 & 19 & 100 & 20 \\
\hline CE4C & 100 & 22 & 100 & 21 & 100 & 21 & 100 & 20 \\
\hline CE4D & 100 & 22 & 100 & 21 & 100 & 18 & 100 & 20 \\
\hline CE5A & 100 & 22 & 100 & 21 & 100 & 18 & 100 & 20 \\
\hline CE5B & 100 & 18 & 100 & 22 & 100 & 19 & 100 & 20 \\
\hline CE6A & 100 & 18 & 100 & 22 & 100 & 18 & 100 & 20 \\
\hline CE7A & 100 & 29 & 100 & 22 & 100 & 18 & 100 & 20 \\
\hline CE7B & 100 & 24 & 100 & 22 & 100 & 18 & 100 & 20 \\
\hline CE8A & 100 & 28 & 100 & 22 & 100 & 17 & 100 & 24 \\
\hline CE8B & 100 & 28 & 100 & 22 & 100 & 17 & 100 & 24 \\
\hline CE9A & 100 & 21 & 100 & 18 & 100 & 17 & 100 & 24 \\
\hline CE10A & 100 & 22 & 100 & 21 & 100 & 17 & 100 & 24 \\
\hline CE10B & 100 & 21 & 100 & 21 & 100 & 17 & 100 & 24 \\
\hline CE11A & 100 & 42 & 100 & 20 & 100 & 17 & 100 & 23 \\
\hline CE12A & 100 & 31 & 100 & 20 & 100 & 24 & 100 & 24 \\
\hline CE12B & 100 & 20 & 100 & 20 & 100 & 24 & 100 & 24 \\
\hline CE12C & 100 & 20 & 100 & 20 & 100 & 23 & 100 & 24 \\
\hline CE13A & 100 & 31 & 100 & 20 & 100 & 23 & 100 & 23 \\
\hline CE13B & 100 & 20 & 100 & 20 & 100 & 23 & 100 & 23 \\
\hline CE14A & 100 & 20 & 100 & 20 & 100 & 21 & 100 & 23 \\
\hline CE14B & 100 & 20 & 100 & 20 & 100 & 19 & 100 & 23 \\
\hline CE14C & 100 & 20 & 100 & 20 & 100 & 19 & 100 & 23 \\
\hline CE15A & 100 & 18 & 100 & 22 & 100 & 19 & 100 & 23 \\
\hline CE15B & 100 & 18 & 100 & 22 & 100 & 19 & 100 & 23 \\
\hline CE17 & 100 & 21 & 100 & 21 & 100 & 19 & 100 & 23 \\
\hline CE18 & 100 & 20 & 100 & 20 & 100 & 12 & 100 & 23 \\
\hline CE19 & 100 & 21 & 100 & 21 & 100 & 19 & 100 & 23 \\
\hline CE20 & 80 & 34 & 100 & 20 & 100 & 19 & 100 & 23 \\
\hline CE21 & 100 & 40 & 100 & 20 & 100 & 18 & 100 & 23 \\
\hline CE22 & 100 & 39 & 100 & 21 & 100 & 18 & 100 & 23 \\
\hline CE23 & 100 & 18 & 100 & 22 & 100 & 18 & 100 & 23 \\
\hline
\end{tabular}




\begin{tabular}{lllllllll}
\hline & \multicolumn{2}{l}{ Potato dextrose agar } \\
\cline { 2 - 8 } Morphotype & 1-month cryopreservation & 6-month cryopreservation & 1-month cryopreservation & 6-month cryopreservation \\
\cline { 2 - 9 } & MV (\%) & TOG (h) & MV (\%) & TOG (h) & MV (\%) & TOG (h) & MV (\%) & TOG (h) \\
\hline CE24 & 100 & 20 & 100 & 20 & 100 & 19 & 100 & 19 \\
CE25 & 100 & 20 & 100 & 20 & 100 & 22 & 100 & 26 \\
Mean & 100 & 23 & 100 & 20 & 100 & 18 & 100 & 22 \\
\hline
\end{tabular}

Table 3. Cellulolytic index of fungi isolated from Brunfelsia uniflora stems.

\begin{tabular}{|c|c|c|c|}
\hline Morphotype & Mycelium diameter $(\mathrm{cm})$ & Halo diameter $(\mathrm{cm})$ & Cellulolytic index \\
\hline CE1A & 4.4 & 0.0 & $0.00^{\mathrm{d}}$ \\
\hline CE1B & 2.3 & 0.0 & $0.00^{\mathrm{d}}$ \\
\hline CE1C & 5.5 & 0.0 & $0.00^{\mathrm{d}}$ \\
\hline CE1E & 6.8 & 0.0 & $0.00^{\mathrm{d}}$ \\
\hline CE2A & 3.6 & 3.6 & $1.00^{\mathrm{c}}$ \\
\hline CE2B & 5.7 & 5.7 & $1.00^{\mathrm{c}}$ \\
\hline CE2C & 6.0 & 6.0 & $1.00^{\mathrm{c}}$ \\
\hline CE2D & 5.6 & 5.6 & $1.00^{\mathrm{c}}$ \\
\hline CE2E & 5.2 & 5.2 & $1.00^{\mathrm{c}}$ \\
\hline CE3A & 6.0 & 6.0 & $1.00^{\mathrm{c}}$ \\
\hline CE3B & 4.6 & 4.6 & $1.00^{\mathrm{c}}$ \\
\hline CE3C & 4.6 & 4.6 & $1.00^{\mathrm{c}}$ \\
\hline CE4A & 3.3 & 3.3 & $1.00^{\mathrm{c}}$ \\
\hline CE4B & 5.0 & 5.0 & $1.00^{\mathrm{c}}$ \\
\hline CE4C & 5.7 & 5.7 & $1.00^{\mathrm{c}}$ \\
\hline CE4D & 4.8 & 4.8 & $1.00^{\mathrm{c}}$ \\
\hline CE5A & 6.4 & 6.8 & $1.06^{\mathrm{b}}$ \\
\hline CE5B & 5.5 & 5.5 & $1.00^{\mathrm{c}}$ \\
\hline CE6A & 4.5 & 0.0 & $0.00^{\mathrm{d}}$ \\
\hline CE7A & 4.5 & 4.8 & $1.07^{\mathrm{b}}$ \\
\hline CE7B & 3.7 & 0.0 & $0.00^{\mathrm{d}}$ \\
\hline CE8A & 4.9 & 4.9 & $1.00^{\mathrm{c}}$ \\
\hline CE8B & 4.4 & 4.4 & $1.00^{\mathrm{c}}$ \\
\hline CE9A & 3.3 & 3.3 & $1.00^{\mathrm{c}}$ \\
\hline CE10A & 2.9 & 3.5 & $1.21^{\mathrm{a}}$ \\
\hline CE10B & 5.6 & 0.0 & $0.00^{\mathrm{d}}$ \\
\hline CE11A & 3.9 & 0.0 & $0.00^{\mathrm{d}}$ \\
\hline CE12A & 5.1 & 5.3 & $1.04^{\mathrm{b}}$ \\
\hline CE12B & 5.9 & 6.2 & $1.05^{\mathrm{b}}$ \\
\hline CE12C & 3.7 & 3.7 & $1.00^{\mathrm{c}}$ \\
\hline CE13A & 2.7 & 0.0 & $0.00^{\mathrm{d}}$ \\
\hline CE13B & 3.5 & 0.0 & $0.00^{\mathrm{d}}$ \\
\hline CE14A & 4.8 & 4.8 & $1.00^{\mathrm{c}}$ \\
\hline CE14B & 4.7 & 4.7 & $1.00^{\mathrm{c}}$ \\
\hline CE14C & 4.6 & 4.6 & $1.00^{c}$ \\
\hline CE15A & 4.6 & 0.0 & $0.00^{\mathrm{d}}$ \\
\hline CE15B & 5.0 & 5.6 & $1.12^{\mathrm{a}}$ \\
\hline CE17 & 4.2 & 4.2 & $1.00^{\mathrm{c}}$ \\
\hline CE18 & 3.7 & 0.0 & $0.00^{\mathrm{d}}$ \\
\hline CE19 & 6.0 & 6.0 & $1.00^{\mathrm{c}}$ \\
\hline
\end{tabular}




\begin{tabular}{llll}
\hline Morphotype & Mycelium diameter $(\mathrm{cm})$ & Halo diameter $(\mathrm{cm})$ & Cellulolytic index \\
\hline CE20 & 2.3 & 2.4 & $1.04^{\mathrm{b}}$ \\
CE21 & 4.0 & 0.0 & $0.00^{\mathrm{d}}$ \\
CE22 & 5.3 & 0.0 & $0.00^{\mathrm{d}}$ \\
CE23 & 3.5 & 3.9 & $1.11^{\mathrm{a}}$ \\
CE24 & 3.5 & $1.00^{\mathrm{c}}$ \\
CE25 & 3.5 & 0.0 & $0.00^{\mathrm{d}}$ \\
\hline
\end{tabular}

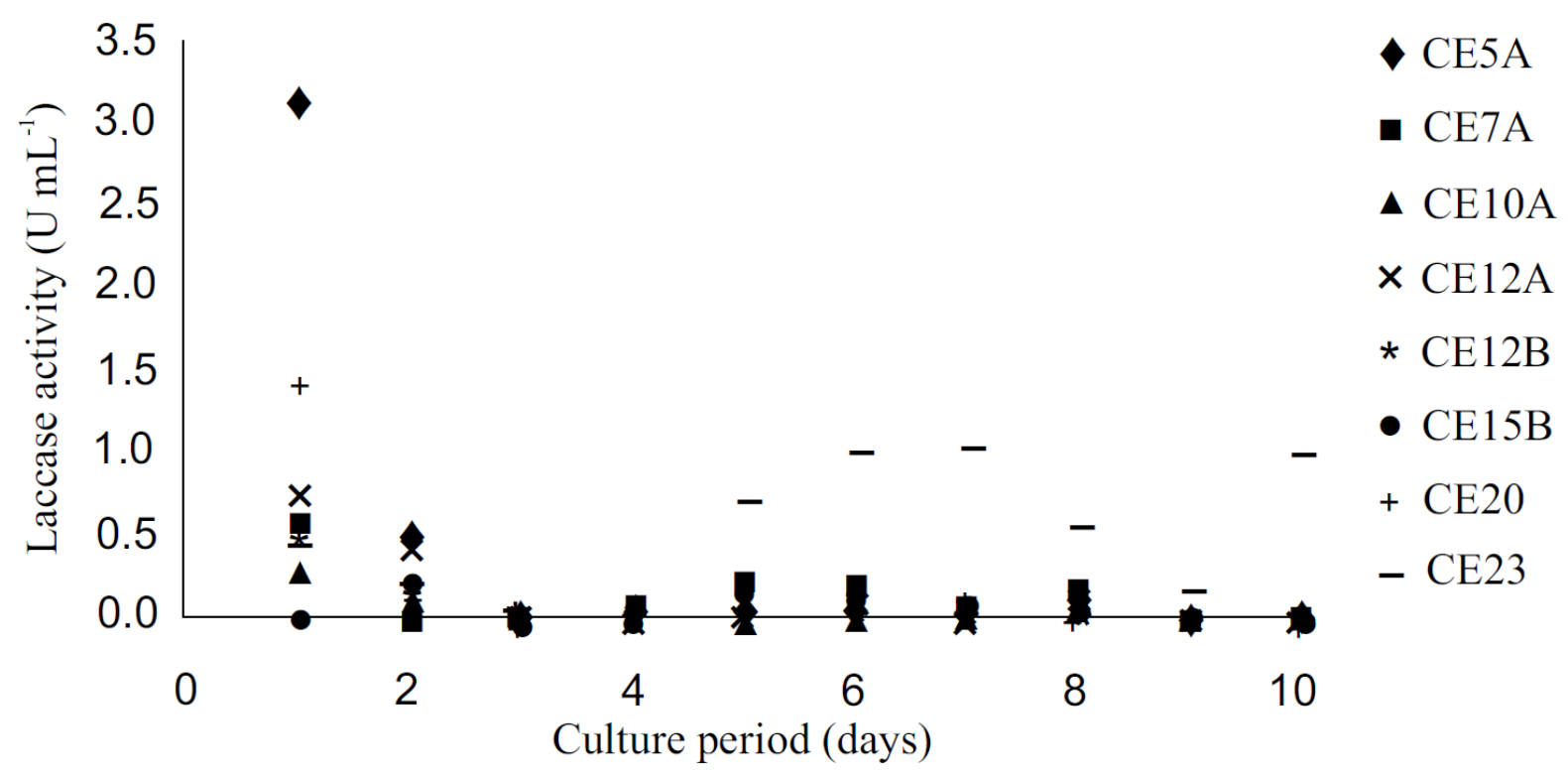

Figure 2. Laccase activity of endophytic fungi isolated from Brunfelsia uniflora stems.

Table 4. Laccase activity of endophytic fungi isolated from Brunfelsia uniflora stems.

\begin{tabular}{ll}
\hline Morphotype & Laccase activity $(\mathrm{U} / \mathrm{mL})$ \\
\hline CE5A & $0.046^{\mathrm{b}}$ \\
CE7A & $0.131^{\mathrm{b}}$ \\
CE10A & - \\
CE12A & $0.007^{\mathrm{b}}$ \\
CE12B & - \\
CE15B & - \\
CE20 & - \\
CE23 & $1.071^{\mathrm{a}}$ \\
\hline
\end{tabular}

Table 5. Antioxidant activity of endophytic fungi isolated from Brunfelsia uniflora stems.

\begin{tabular}{lllll}
\hline Morphotype & $\begin{array}{l}D P P H \bullet \text { scavenging activity } \\
(\mu \mathrm{g} \mathrm{QE} / \mathrm{mg})\end{array}$ & $\begin{array}{l}\mathrm{DPPH} \cdot \mathrm{IC}_{50} \\
(\mathrm{mg} / \mathrm{mL})\end{array}$ & $\begin{array}{l}\text { FRAP activity } \\
\left(\mu \mathrm{M} \mathrm{Fe}_{2} \mathrm{SO}_{4} / \mathrm{mg}\right)\end{array}$ & $\begin{array}{l}\text { Total phenolics } \\
(\mu \mathrm{g} / \mathrm{mg})\end{array}$ \\
\hline CE1A & $0.747 \pm 0.008$ & $\mathrm{nt}$ & $\mathrm{nt}$ & $\mathrm{nt}$ \\
CE1B & $0.784 \pm 0.030$ & $\mathrm{nt}$ & $\mathrm{nt}$ & $\mathrm{nt}$ \\
CE1C & $0.643 \pm 0.014$ & $\mathrm{nt}$ & $\mathrm{nt}$ & $\mathrm{nt}$ \\
CE1E & $1.016 \pm 0.009$ & $43.055 \pm 5.830$ & $0.047 \pm 0.001$ & $42.473 \pm 1.320$ \\
CE2A & $0.271 \pm 0.005$ & $\mathrm{nt}$ & $\mathrm{nt}$ & $\mathrm{nt}$ \\
CE2B & $0.569 \pm 0.016$ & $\mathrm{nt}$ & $\mathrm{nt}$ & $\mathrm{nt}$ \\
CE2C & $0.345 \pm 0.005$ & $\mathrm{nt}$ & $\mathrm{nt}$ & $\mathrm{nt}$ \\
CE2D & $0.383 \pm 0.023$ & $\mathrm{nt}$ & $\mathrm{nt}$ & $\mathrm{nt}$ \\
\hline
\end{tabular}




\begin{tabular}{|c|c|c|c|c|}
\hline Morphotype & $\begin{array}{l}D P P H \bullet \text { scavenging activity } \\
(\mu \mathrm{g} \mathrm{QE} / \mathrm{mg})\end{array}$ & $\begin{array}{l}D P P H \cdot \mathrm{IC}_{50} \\
(\mathrm{mg} / \mathrm{mL})\end{array}$ & $\begin{array}{l}\text { FRAP activity } \\
\left(\mu \mathrm{M} \mathrm{Fe}_{2} \mathrm{SO}_{4} / \mathrm{mg}\right)\end{array}$ & $\begin{array}{l}\text { Total phenolics } \\
(\mu \mathrm{g} / \mathrm{mg})\end{array}$ \\
\hline CE2E & $0.312 \pm 0.002$ & $\mathrm{nt}$ & $\mathrm{nt}$ & nt \\
\hline CE3A & $0.554 \pm 0.027$ & $\mathrm{nt}$ & $\mathrm{nt}$ & $\mathrm{nt}$ \\
\hline CE3B & $0.329 \pm 0.026$ & $\mathrm{nt}$ & nt & $\mathrm{nt}$ \\
\hline CE3C & $0.547 \pm 0.021$ & $\mathrm{nt}$ & $\mathrm{nt}$ & $\mathrm{nt}$ \\
\hline CE4A & $0.530 \pm 0.021$ & nt & nt & $\mathrm{nt}$ \\
\hline CE4B & $0.474 \pm 0.021$ & $\mathrm{nt}$ & nt & $\mathrm{nt}$ \\
\hline CE4C & $0.516 \pm 0.071$ & $\mathrm{nt}$ & $\mathrm{nt}$ & nt \\
\hline CE4D & $0.366 \pm 0.027$ & $\mathrm{nt}$ & $\mathrm{nt}$ & $\mathrm{nt}$ \\
\hline CE5A & $0.563 \pm 0.024$ & $\mathrm{nt}$ & $\mathrm{nt}$ & $\mathrm{nt}$ \\
\hline CE5B & $0.701 \pm 0.119$ & $\mathrm{nt}$ & $\mathrm{nt}$ & $\mathrm{nt}$ \\
\hline CE6A & ns & $\mathrm{nt}$ & $\mathrm{nt}$ & $\mathrm{nt}$ \\
\hline CE7A & $0.753 \pm 0.024$ & $\mathrm{nt}$ & $\mathrm{nt}$ & $\mathrm{nt}$ \\
\hline CE7B & $0.724 \pm 0.051$ & $\mathrm{nt}$ & $\mathrm{nt}$ & $\mathrm{nt}$ \\
\hline CE8A & $0.309 \pm 0.034$ & $\mathrm{nt}$ & $\mathrm{nt}$ & $\mathrm{nt}$ \\
\hline CE8B & $0.404 \pm 0.137$ & $\mathrm{nt}$ & nt & $\mathrm{nt}$ \\
\hline CE9A & $0.575 \pm 0.011$ & $\mathrm{nt}$ & $\mathrm{nt}$ & $\mathrm{nt}$ \\
\hline CE10A & $0.296 \pm 0.063$ & $\mathrm{nt}$ & $\mathrm{nt}$ & $\mathrm{nt}$ \\
\hline CE10B & $0.882 \pm 0.053$ & nt & $\mathrm{nt}$ & nt \\
\hline CE11A & $1.336 \pm 0.005$ & $29.240 \pm 1.832$ & $0.028 \pm 0.0007$ & $31.473 \pm 0.099$ \\
\hline CE12A & $0.662 \pm 0.010$ & nt & nt & $\mathrm{nt}$ \\
\hline CE12B & $1.259 \pm 0.034$ & $50.547 \pm 3.349$ & $0.027 \pm 0.005$ & $40.868 \pm 2.019$ \\
\hline CE12C & $0.293 \pm 0.034$ & $\mathrm{nt}$ & $\mathrm{nt}$ & $\mathrm{nt}$ \\
\hline CE13A & ns & $\mathrm{nt}$ & $\mathrm{nt}$ & $\mathrm{nt}$ \\
\hline CE13B & $0.185 \pm 0.026$ & $\mathrm{nt}$ & nt & $\mathrm{nt}$ \\
\hline CE14A & $1.341 \pm 0.003$ & $15.049 \pm 0.017$ & $0.061 \pm 0.001$ & $55.296 \pm 3.536$ \\
\hline CE14B & $1.229 \pm 0.045$ & $66.974 \pm 6.185$ & $0.040 \pm 0.014$ & $30.960 \pm 0.296$ \\
\hline CE14C & $0.998 \pm 0.012$ & $\mathrm{nt}$ & $\mathrm{nt}$ & $\mathrm{nt}$ \\
\hline CE15A & $0.985 \pm 0.040$ & $\mathrm{nt}$ & nt & $\mathrm{nt}$ \\
\hline CE15B & $5.849 \pm 0.006^{\mathrm{a}}$ & $17.122 \pm 1.054$ & $0.030 \pm 0.001$ & $25.710 \pm 0.975$ \\
\hline CE17 & $0.685 \pm 0.027$ & $\mathrm{nt}$ & $\mathrm{nt}$ & $\mathrm{nt}$ \\
\hline CE18 & $1.315 \pm 0.003$ & $18.281 \pm 0.386$ & $0.027 \pm 0.017$ & $40.822 \pm 3.341$ \\
\hline CE19 & $1.295 \pm 0.041$ & $15.716 \pm 0.393$ & $0.015 \pm 0.001$ & $16.039 \pm 1.314$ \\
\hline CE20 & $0.749 \pm 0.045$ & $\mathrm{nt}$ & $\mathrm{nt}$ & $\mathrm{nt}$ \\
\hline CE21 & $1.342 \pm 0.009$ & $70.138 \pm 2.553$ & $0.021 \pm 0.015$ & $20.776 \pm 1.641$ \\
\hline CE22 & $1.354 \pm 0.002$ & $20.776 \pm 1.503$ & $0.030 \pm 0.002$ & $28.697 \pm 2.408$ \\
\hline CE23 & $1.344 \pm 0.001$ & $40.205 \pm 1.094$ & $0.024 \pm 0.011$ & $22.118 \pm 1.729$ \\
\hline CE24 & $1.193 \pm 0.05$ & $15.818 \pm 0.327$ & $0.037 \pm 0.001$ & $67.598 \pm 3.040$ \\
\hline CE25 & $\mathrm{ns}$ & $\mathrm{nt}$ & $\mathrm{nt}$ & $\mathrm{nt}$ \\
\hline Trolox & - & - & $9.325 \pm 0.670$ & - \\
\hline Quercetin & $0.060 \pm 0.003$ & $0.031 \pm 0.002$ & - & - \\
\hline
\end{tabular}

